\title{
In Vitro/ Ex Vivo Antiplasmodial Activity and Phytochemical Screening of Crude Extracts Entandrophragma angolense (Welw.) C. DC., Griffonia simplicifolia (Vahl ex DC.) Baill .et Uapaca guineensis Müll. Arg. three Plants of Ivorian Pharmacopeia in the Treatment of Malaria
}

\author{
M.R. Offoumou ${ }^{1 *}$, G.R. Kipre ${ }^{2}$, D.S. Kigbafori ${ }^{3,4}$, D. Camara ${ }^{1}$, \\ A.J. Djaman ${ }^{2,5}$ and G.N. Zirihi ${ }^{1}$ \\ ${ }^{1}$ Université Félix Houphouët-Boigny, Laboratoire de Botanique, UFR Biosciences, \\ Abidjan, Côte d'Ivoire. \\ ${ }^{2}$ Université Félix Houphouët Boigny, Laboratoire de Pharmacodynamie Biochimique, \\ UFR Biosciences, Abidjan, Côte d'Ivoire. \\ ${ }^{3}$ Université Félix Houphouët Boigny, Laboratoire de Zoologie et Biologie Animale, \\ UFR Biosciences, Abidjan, Côte d'Ivoire. \\ ${ }^{4}$ Centre Suisse de Recherches Scientifiques en Côte d'Ivoire (CSRS), Abidjan, Côte d'Ivoire \\ ${ }^{5}$ Laboratoire de Biochimie, Institut Pasteur de Côte d'Ivoire \\ *Corresponding author
}

\section{A B S T R A C T}

\section{Keywords}

Medicinal plants, Antiplasmodial, Sybr green, Plasmodium falciparum, Agboville

\section{Article Info}

Accepted:

16 February 2018

Available Online:

10 March 2018
The drug resistance of Plasmodium falciparum to different antimalarials, even recently to artemisinin derivatives, complicates the fight against malaria. This disease remains the leading cause of consultation in the health structures in Ivory Coast. It is therefore urgent to identify new molecules from the traditional pharmacopoeia that is very popular in Africa and recommended by WHO. The general objective of this study is the valorization of the Ivorian pharmacopeia by in vitro/ ex vivo evaluation of the antiplasmodial activity and carry out a phytochemical screening of crude extracts. We tested 6 crude extracts including 3 aqueous and 3 ethanolic on clinical isolates on the one hand and reference strains of chloroquine-sensitive $P$. falciparum (NF54) and chloroquine-resistant (K1) on the one hand. And we have investigated phytochemical screening by standard protocols. The inhibition of erythrocyte schizogony was determined by measuring the fluorescence of Sybr green intercalated in the parasite DNA, using a spectrofluorimeter. Then the IC50 values were determined by the online software ICEstimator antimalarial version 1.2. All the aqueous and ethanolic extracts of the three plants inhibit the growth of the parasite (Plasmodium falciparum). The aqueous extracts of Entandrophragma angolense (Is: $1,66 \pm 0,16 \mu \mathrm{g} / \mathrm{mL} ; \mathrm{NF} 54: 3,85 \mu \mathrm{g} / \mathrm{mL}$ et $\mathrm{K} 1: 6 \mu \mathrm{g} / \mathrm{mL}$ ) and Griffonia simplicifolia (Is: $1,48 \pm 0,08 \mu \mathrm{g} / \mathrm{mL}$; NF54 :1,91 $\mu \mathrm{g} / \mathrm{mL}$ et $\mathrm{K} 1: 12,66 \mu \mathrm{g} / \mathrm{mL}$ ) have the best antimalarial activity. The different extracts are rich in alkaloid, sterols and polyterpenes, saponin then polyphenols and flavonoid. The results therefore justify the traditional use of the plants in the treatment of malaria in the Department of Agboville (Ivory Coast). 


\section{Introduction}

Malaria is a parasitosis caused by hématozoaires of the genus Plasmodium which is the most serious form. It is caused by Plasmodium falciparum and it is transmitted by infected mosquitos of the genus Anopheles (Mouchetet Carnevale, 2004). Malaria is a real public health problem and a major obstacle to the development of endemic countries. In 2015, one estimates at 214 million the number of new cases of malaria, and approximately at 438000 the number of deaths occur in Sub-Saharan Africa, with children younger than five years of age and pregnant women being the most severely affected (OMS, 2016). The fight against this pathology by the affected populations contributes to the process of exhaustion of household capital and loss of income and therefore reduces their consumption (Gallup et al., 2001 and Russel, 2004). More worrying is the drug resistance of Plasmodium falciparum to different antimalarials, even recently to artemisinin derivatives (Dondorp, 2009). The situation becomes critical and complicates the fight against this affection. It is for all these difficulties that the whole world is looking for a lasting solution to eradicate this scourge. And among these solutions traditional medicine is a remedy of choice since it is even recommended by WHO.

According to WHO (2002), more than $80 \%$ of the African population uses plants for their health care needs. It is now estimated that about one-third (1/3) of the drugs currently on the market contain at least one herbal substance (Newman and Cragg, 2012).

It is therefore urgent to identify new molecules from the traditional pharmacopoeia that is very popular in Africa and recommended by WHO. Because these populations are generally poor and the traditional drugs are accessible, less expensive and are registered in the sociocultural practices.

The principal objective of this t study was to evaluate in vitro and ex vivo the antiplasmodial activity and carry out a screening phytochimic crude extracts of three plants from Ivorian pharmacopoeia.

\section{Materials and Methods}

\section{Collection of plants material}

The plants were collected in Department of Agboville (South-Eastern of the Ivory Coast). The plant materials were identified by Floristic Center of Félix Houphouët-Boigny University. A voucher herbarium specimen is deposited at the Floristic Center. There are three plants such as barks of tem of Entandrophragma angolense (Welw.) C. DC., Uapaca guineensis Müll. Arg. and leaves of Griffonia simplicifolia (Vahl ex DC.) Baill.

\section{Preparation of crude extracts of three plants}

The samples of the plants were with the shelter of the sun during two weeks at ambient temperature before being reduced out of fine powder by crushing using a mechanical crusher. According to the protocol of extraction of Zirihi et al., (2003), hundred grams $(100 \mathrm{~g})$ of powders were dissolved in one (1L) liter of water distilled by crushing in Blinder during 10 to 15 minutes. The homogenate obtained is initially dried in a fabric square, then filtered successively twice on absorbent cotton and once on paper Whatman $3 \mathrm{~mm}$. The filtrate obtained was dried at $50^{\circ} \mathrm{C}$. The evaporate will be recovered in the form of powder which constituted our aqueous extracts. The same operation was repeated with the solvent ethanolic $70 \%$ leading to our extracts 
ethanolic. That enabled us to have 24 extracts including 12 aqueous extracts and 12 extracts ethanolic. The homogenate obtained is first spun in a square of fabric, then filtered successively twice on hydrophilic cotton and once on Whatman paper $3 \mathrm{~mm}$. The filtrate obtained was dried by evaporation in a Venticell oven at $50^{\circ} \mathrm{C}$. The evaporate will be recovered in the form of a powder which constituted our aqueous extracts. The same operation was repeated with $70 \%$ ethanolic solvent leading to our ethanolic extracts. This allowed us to have 6 extracts including 3 aqueous extracts and 3 ethanolic extracts.

\section{Collection of blood samples for ex vivo sensitivity test}

We collected intravenous blood samples in heparinized tubes from patients (informed and consenting) with simple falciparum monoinfection malaria confirmed by a rapid diagnostic test.

\section{Preparation of culture medium and extracts solution}

The culture medium used is RPMI 1640 (Rosewell Park Memorial Institute). The medium was obtained by dissolving in $900 \mathrm{ml}$ of distilled water $10.44 \mathrm{~g}$ of RPMI 1640, 5.94 $\mathrm{g}$ of HEPES, $2.1 \mathrm{mg}$ of $\mathrm{NaHCO}_{3}, 100 \mathrm{mg}$ of Neomycin (an antibiotic, to avoid bacterial contamination), $50 \mathrm{mg}$ of hypoxanthine, and 5 $\mathrm{g}$ of albumax. The volume of the mixture obtained was adjusted to 1 liter, then sterilized by filtration with $0.22 \mu \mathrm{m}$ stericup and aliquoted in tubes of $50 \mathrm{ml}$ conical bottom, hermetically closed, then kept at $4{ }^{\circ} \mathrm{C}$ before the arrival of clinical isolates.

A concentration range ( $1 / 2$ dilution) was prepared from a $100 \mu \mathrm{g} / \mathrm{mL}$ stock solution after addition of $100 \mu \mathrm{L}$ of inoculum for the extracts in 96-well plates filled with a fixed volume $(200 \mu \mathrm{L})$. The concentration range was therefore $100 \mu \mathrm{g} / \mathrm{mL}$ at $1.5625 \mu \mathrm{g} / \mathrm{mL}$ with $\mathrm{C} 1=100 ; \mathrm{C} 2=50 ; \mathrm{C} 3=25 ; \mathrm{C} 4=12.5$; $\mathrm{C} 5=6.25 ; \mathrm{C} 6=3.125 ; \mathrm{C} 7=1.5625 \mu \mathrm{g} / \mathrm{mL}$

\section{Antiplasmodial evaluations}

Parasitemia is determined but in case of parasitaemia greater than $0.3 \%$, a dilution with healthy $\mathrm{O}+$ cells was performed to have parasitaemias $<0.3 \%$. Then the inoculum is prepared from parasitized blood pellets and RPMI 1640 supplemented with $0.5 \%$ of albumax (complete medium) to obtain a hematocrit of $5 \%$. For in vitro tests, the chloroquine-sensitive (NF54) and chloroquine-resistant (K1) strains were maintained in continuous culture (Trager and Jensen, 1976). Parasites were synchronized for in vitro tests with D-sorbitol at $5 \%$.

Then parasitized red blood cells were exposed to the different drugs, then incubated for 72 hours at $37^{\circ} \mathrm{C}$ under a candle bell. The Rieckmannmicrotest technique adopted by WHO (Rieckmann et al., 1978) was used and the Florescence was measured after exposure to SYBR green in the dark for one hour at room temperature.

The antimalarial activity or the inhibition of erythrocyte schizogony was determined by measuring the fluorescence of Sybr green intercalated in the parasite DNA, using a spectrofluorimeter. Then the IC50 values (concentration of extract inhibiting 50\% of parasite growth) were determined by the online software ICEstimator antimalarial version 1.2 (Kaddouri et al., 2006, Nagard et al., 2011).

\section{Phytochemical screening}

The phytochemical screening was done using the standard protocols (Uddin et al., 2012; Usman et al., 2012) to detect the presence or absence of certain bioactive compounds. 


\section{Results and Discussion}

\section{Antiplasmodial evaluations}

The total aqueous and ethanol extracts prepared from barks of Entandrophragma angolense, Uapaca guineensis and leaves of Griffonia simplicifolia were tested in clinical isolates, chloroquine-sensitive (NF54) and chloroquine-resistant $\mathrm{P}$. falciparum reference strains. (K1). In our study, all crude extracts tested showed antimalarial activity on all strains (Table 1). In vitro antiplasmodial activity of our crude extracts is classified as high $\left(\mathrm{IC}_{50}<5 \mu \mathrm{g} / \mathrm{mL}\right)$, promising $\left(5<\mathrm{IC}_{50}<15\right.$ $\mu \mathrm{g} / \mathrm{mL})$, and moderate $\left(15<\mathrm{IC}_{50}<50 \mu \mathrm{g} / \mathrm{mL}\right)$ according to the classification scale of some authors (Bero and Quetin-Leclercq, 2011; Jansen et al., 2012).

\section{Phytochemical screening}

Phytochemical screening performed on the 6 total extracts showed the presence of several secondary metabolites summarized in Table 2. In general, the various extracts are rich in alkaloid, sterols and polyterpenes, saponin and polyphenols and flavonoid. On the other hand, they are poor in catechetical tannins.

Extracts of Entandrophragma angolense made up of almost all the chemical groups studied.

Table.1 Results of the antiplasmodial tests of the crude extracts of the studied plants

\begin{tabular}{|l|l|l|l|l|}
\hline Selected Plants & Extracts & $\begin{array}{l}\text { Moyennes CI50 } \\
(\boldsymbol{\mu g} / \mathbf{m L}) \text { des isolates }\end{array}$ & NF54 & K1 \\
\hline Griffonia simplicifolia & $\mathrm{Aq}$ & $1,48 \pm 0,08$ & $1,91 \pm 0,08$ & $12,66 \pm 2,67$ \\
\hline \multirow{2}{*}{ Entandrophragma angolense } & $\mathrm{eth}$ & $3,85 \pm 0,42$ & $4,05 \pm 1,21$ & $21,33 \pm 2,52$ \\
\hline \multirow{2}{*}{ Uapaca guineensis } & $\mathrm{Aq}$ & $1,66 \pm 0,16$ & $3,85 \pm 0,51$ & $6 \pm 0,28$ \\
\hline & eth & $18,39 \pm 2,50$ & $12,67 \pm 1,2$ & $20 \pm 2,53$ \\
\hline CHLOROQUINE (nM) & $\mathrm{Aq}$ & $11,54 \pm 1,71$ & $12 \pm 2,20$ & $24,38 \pm 3,97$ \\
\hline & eth & $25,59 \pm 6,38$ & $23 \pm 2,86$ & $42 \pm 0,37$ \\
\hline & & 15,88 & 11,03 & 124,74 \\
\hline
\end{tabular}

Aq :aqueux ; eth : ethanol

Tables.2 Results of the phytochemical screening of the aqueous and ethanolic crude extracts of the studied plants

\begin{tabular}{|c|c|c|c|c|c|c|c|c|}
\hline Plants & Extraits & $\begin{array}{l}\text { Stérols et } \\
\text { polyterpènes }\end{array}$ & Polyphénols & flavonoids & $\begin{array}{l}\text { Catechism } \\
\text { tannins }\end{array}$ & Quinones & alkaloids & $\begin{array}{l}\text { sapo } \\
\text { nins }\end{array}$ \\
\hline \multirow{2}{*}{$\begin{array}{l}\text { Entandrophragma } \\
\text { angolense }\end{array}$} & $\mathrm{Aq}$ & + & + & + & ++ & + & ++ & \multirow[t]{2}{*}{++} \\
\hline & eth & ++ & ++ & + & - & - & + & \\
\hline \multirow[t]{2}{*}{ Griffonia simplicifolia } & $\mathrm{Aq}$ & + & - & - & - & + & + & \multirow[t]{2}{*}{+} \\
\hline & eth & ++ & - & - & - & ++ & ++ & \\
\hline \multirow[t]{2}{*}{ Uapaca guineensis } & $\mathrm{Aq}$ & - & + & + & - & - & ++ & \multirow[t]{2}{*}{-} \\
\hline & eth & + & ++ & ++ & - & + & + & \\
\hline
\end{tabular}

Extracts of Entandrophragma angolense made up of almost all the chemical groups studied. 
An ethnobotanical survey allowed us to know that Entandrophragma angolense, Uapaca guineensis and Griffonia simplicifolia are three plants used by the traditional health practitioners of the Department of Agboville for the treatment of malaria. These plants have been evaluated for the purpose of scientifically justifying their traditional use. We therefore tested 6 crude extracts including 3 aqueous and 3 ethanolic on clinical isolates (4) on the one hand and reference strains of chloroquine-sensitive P. falciparum (NF54) and chloroquine-resistant (K1) on the one hand. All crude extracts tested have different antimalarial effects.

The aqueous extracts of Entandrophragma angolense and Griffonia simplicifolia have high antimalarial activity (IC50<5 $\mu \mathrm{g} / \mathrm{mL}$ ) . Their IC50 in both clinical isolates, the chloroquine-sensible strain are respectively (Is: $1,66 \pm 0,16 \mu \mathrm{g} / \mathrm{mL}$ et NF54: $3,85 \mu \mathrm{g} / \mathrm{mL}$ ) and (Is: $1,48 \pm 0,08 \mu \mathrm{g} / \mathrm{mL}$; NF54 :1,91 $\mu \mathrm{g} /$ $\mathrm{mL})$. However antiplasmodial activity on the resistant strain $\mathrm{K} 1$ de aqueous extracts of Entandrophragma angolense (K1: $6 \mu \mathrm{g} / \mathrm{mL})$

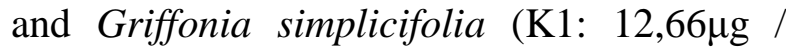
$\mathrm{mL}$ ) is promising. Concerning Uapaca guineensis, the aqueous and ethanolicexraits on the reference strains respectively show a moderate antimalarial activity (NF54: $12 \mu \mathrm{g} /$ $\mathrm{mL}$ et $\mathrm{K} 1: 24,38 \mu \mathrm{g} / \mathrm{mL}$ ) et (NF54: $23 \mu \mathrm{g} /$ $\mathrm{mL}$ et $\mathrm{K} 1: 42 \mu \mathrm{g} / \mathrm{mL}$ ).

In the literatura we have not found any data on the in vitro or ex vivo activity of Uapaca guineensiset Griffonia simplicifolia on Plasmodium. But Bickii et al., (2007) showed that them ethanolic extract of Entandrophragma angolense bark on the chloroquine-resistant W2 strain on Plasmodium falciparum has an IC50 between 2 and $5.4 \mu \mathrm{g} / \mathrm{mL}$. This is what we confirmed in our study $(\mathrm{K} 1: 6 \mu \mathrm{g} / \mathrm{mL})$.

In our study all clinical isolates tested for malaria were chloroquine-sensitive according to the classification scale of Susan et al., (1994) because the IC50 obtained with the use of chloroquine is less than $100 \mathrm{nM}$. Considering the number of isolates (4) studied, these results cannot be extrapolated to decide on the reversion (or not) of the resistance of Plasmodium falciparum to chloroquine made possible by the acquisition of a new mutation due to the withdrawal of this molecule of the national market since 2007.

However, a study carried out in the same site (at the Wassakara Community Based Health Training) on the ex-vivo resistance profile of clinical isolates (94) of Plasmodium falciparum to antimalarial compounds showed us that resistance to chloroquine is $13.6 \%$ (SIPAM, 2016) is still present although it has decreased by comparing these results with those obtained by Djaman et al., (2004) which was $36 \%$.

All these plants used by the health care specialists of the Department of Agboville for the treatment of malaria are indeed plants with antimalarial activity. The results obtained also find a justification in the composition of these plants which have several secondary metabolites involved in the treatment of malaria. These natural products have antioxidant, antimicrobial, antiinflammatory, anti-cancer pharmaceutical properties (Epifano et al., 2007), antiparasitics (Portet et al., 2007).

More particularly alkaloids, phenols, saponins, triterpenoids, flavonoids, quinones present in our extracts have antiplasmodial properties (Krief, 2003, Omoregie and Osagie, 2011, Omoregie et al., 2011, Zofou et al., 2011, Ravikumar et al., 2012). Also according to Iwalewa et al., (2007) flavonoids, tannins and alkaloids have antiinflammatory properties. They thus participate in the cure of malaria as well as saponins which are known to improve feeding 
in animals, which is necessary in the condition of loss of appetite that occurs with malaria (Liu, 2004).

In this study we have concluded that the total aqueous and ethanolic extracts prepared from bark of Entandrophragma angolense ,Uapaca guineensiset leaves of Griffonia simplicifolia are antiplasmodial activity. The aqueous extracts of Entandrophragma angolense and Griffonia simplicifolia have the best antimalarial activity. Also certain secondary metabolites (alkaloids, phenols, saponins, triterpenoid, flavonoid, quinones) with antiplasmodial property present in our plants confirm our results. The results therefore justify the traditional use of the plant in the treatment of malaria in the Department of Agboville (Ivory Coast).

We plan to do toxicological studies on these medicinal plants to determine their safety.

\section{Acknowledgement}

We thank the traditional health practitioners of the Department of Agboville and we plan to give them feedback on the results of this work.

\section{References}

Bero J. and Quetin-Leclercq J. 2011. Natural products published in 2009 from plants traditionnaly used to treat malaria. Planta Medicine, 77: 631-640.

Bickii J., Tchouya, G.R.F, Tchouankeu J.C., Tsamo E. 2007. The antiplasmodial agents of the stem bark of Entandrophragma angolense (Meliaceae). Afr. J. Trad.CAM, 4(2): 135 - 139

Dondorp A., Nosten F., Yi P., Das D., Phyo A.P., Tarning J., Lwin K.M., Ariey F., Hanpithakpong W., Lee S.J., Ringwald P., Silamut K., Imwong M., Chotivanich
K., Lim P., Herdman T., An S.S., Yeung S., Singhasivanon P., Day N.P., Lindegardh N., Socheat D., White N.J., 2009.- Artemisinin resistance in Plasmodium falciparum malaria. The New England Journal Med., 361, 45567.

Epifano, F., Genovese, S., Menghini, L., Curini, M. 2007. Chemistry and pharmacology of oxyprenylated secondary plant metabolites, Review. Phytochemistry 68, 939-953.

Frappier, F., A. Laurens, R. Hocquemiller. 2004. Antiparasitic activities of medicinal plants used in Ivory Coast / Journal of Ethnopharmacology 90: 9197.

Gallup JL, Sachs JD. 2001. The economic burden of malaria. American Journal of Tropical Medicine and Hygiene, 64, 1-2 Suppl., Pp. 85-96.

Iwalewa, E. O., McGraw, L, J., Naidoo, V. and Eloff, J. N. 2007. Inflammation: the foundation of diseases and disorders. A review of phytomedicines of South African origin used to treat pain and inflammatory conditions. African Journal of Biotechnology, 6(25): 28682885.

Jansen O., Tits M., Angenot L., Nicolas J.P., De Mol P., Nikiema J.B. and Frédérich M. 2012. Anti-plasmodial activity of Dicomatomentosa (Asteraceae) and identification of urospermal A-15- Oacetate as the main active compound, Malaria Journal, 11:1-9.

Kaddouri H, Nakache S, Houzé S, Mentré F, Le Bras J. 2006.- Drug Susceptibility of Plasmodium falciparum Clinical Isolates from Africa using Plasmodium Lactate Dehydrogenase Immunodetection Assay and inhibitory Emax model for precise IC50 measurement. Antimicrobial Agents and Chemotherapy, 50: 33433349.

Krief S., 2003. Métabolites secondaires des 
plantes et comportement animal : surveillance sanitaire et observations de l'alimentation de chimpanzés (pan troglodytes schweinfurthii) en ouganda activités biologiques et étude chimique de plantes consommées. thèse muséum national d'histoire naturelle, $346 \mathrm{p}$.

Le Nagard H, Vincent C, Mentré F, Le Bras J. 2011.- Online analysis of in vitro resistance to antimalarial drugs through nonlinear regression. Computer Methods and Programs in Biomedicine, 104: 108.

Liu R.H., (2004) Potential synergy of phytochemicals in cancer prevention: mechanism of action, J. Nutrition 134 3479S-3485S.

Mouchet J. and Carnevale P., 2004.-Les vecteurs de la transmission. In Danis $M$. et Mouchet J, le paludisme. Ed. Marketing Ellipse/Aupelf. Paris, pp 3558.

Newman D.J. and Cragg G.M., 2012. Natural Products As Sources of New Drugs over the 30 Years from 1981 to 2010. J. Nat. Prod., 75, 311-335.

Omoregie, E.S., Pal, A., Sisodia, B., 2011.In vitroantimalarial and cytotoxic activities of leaf extracts of Vernoniaamygdalina (Del.). Niger. J. Basic Appl. Sci. 19, 121-126.

Okpekon T, Yolou S., GleyeC.Roblot, F., Loiseau P., Bories C., Grellier P. Omoregie, E.S. and Osagie, A.U. (2011). Effect of J. Tanjorensis leaves supplement on the activities of some antioxidant enzymes, vitamins and lipid peroxidation in rats. Journal of Food Biochemistry, 35(2): 409-424.

OMS, 2016.- Aide-mémoire N94 Janvier 2016

OMS, 2002. Stratégie de l'OMS pour la médecine traditionnelle pour 2002-2005.

Portet B. (2007). Recherche bioguidée de molecules antipaludiques d'une plante guyanaise Piper hostmannianum var. berbicense. Thèse de doctorat de l'Université Toulouse III - Paul Sabatier, $221 p$.

Ravikumar, S., Inbaneson, S.J. and Suganthi, P. 2012. In vitro antiplasmodial activity of ethanolic extracts of South Indian medicinal plants against Plasmodium falciparum. Asian Pacific Journal of Tropical Biomedicine, 1-9.

Russel S. 2004. The economic burden of illness for households in developing countries: a review of studies focusing on malaria, Tuberculosis, and human immunodeficiency virus/acquired immunodeficiency syndrome, American Journal of Tropical Medicine and Hygiene, 71 (suppl. 2), 147-155.

SIPAM, 2016.- Livre résumé définitif du $2^{\text {ème }}$ Congrès de la Société Ivoirienne de Parasitologie et de Mycologie: « Interventions contre les maladies parasitaires et mycosiques et atteinte des Objectifs du Millénaire pour le Développement - Perspectives pour les Objectifs de Développement Durable », pp 92-93.

Susan E.F., Ilya Y.G., Anna O., Aron K., Richard M., Martin L.B., David R.S. David G.R. and Daniel E.G. (1994). Molecular characterization and inhibition of a Plasmodium falciparum aspartic hemoglobinase. EMBO Journal. 13:306-317.

Trager W., Jensen J. B. (1976).Human malaria parasites in continuous culture. Science 193:673-675.

Uddin, G.A., Rauf, M., Arfan, M., Ali, M., Qaisar, M., Saadiq, Atif, M. 2012.Preliminary phytochemical Screening and antioxidant activity of Bergenia Ciliata. Middle-East J. Sci Res., 11(8):1140-1142.

Usman, R., Khan, A., Gul, S., Rauf, A., Muhammad, N. 2012. Preliminary AntiOxidant Profile of Selected Medicinal Plants of Pakistan. Middle-East J Med 
Plants Res., 1(2):24-7.

WHO,2001. Antimalarial Drug Combination Therapy: Report of a Who Technical Consultation 35.

OMS, 2002. Stratégie de l'OMS pour la médecine traditionnelle pour 2002-2005. WHO/EDM/TRM/2002, Genève: 65.

Zofou, D., Tene, M., Ngemenya, M.N., Tane, P. and Titanji, V.P.K. 2011. In vitro antiplasmodial activity and cytotoxicity of extracts of selected medicinal plants used by traditional healers of western Cameroon. Malaria Research and Treatment, DOI: 10.4061/2011/561342.

Zirihi GN, Kra AM, Guédé-Guina F. 2003. Évaluation de l'activité antifongique de Microglossapyrifolia (Lamarck) O. Kunze (Asteraceae) PYMI sur la croissance in vitro de Candida albicans. Méd. et Pharm. Afr., 17: 11-18.

\section{How to cite this article:}

Offoumou, M.R., G.R. Kipre, D.S. Kigbafori, D. Camara, A.J. Djaman and G.N. Zirihi. 2018. In Vitro/ Ex Vivo Antiplasmodial Activity and Phytochemical Screening of Crude Extracts Entandrophragma angolense (Welw.) C. DC., Griffonia simplicifolia (Vahl ex DC.) Baill .etUapaca guineensis Müll. Arg. Three Plants of Ivorian Pharmacopeia in the Treatment of Malaria. Int.J.Curr.Microbiol.App.Sci. 7(03): 2088-2095.

doi: https://doi.org/10.20546/ijcmas.2018.703.245 